\title{
Keragaman Kualitas Buah pada Dua Varietas Okra (Abelmoschus esculentus L. Moench) dari Umur Panen Berbeda
}

\section{Variation in Fruits Quality of Two Okra Varieties (Abelmoschus esculentus L. Moench) from Different Harvest Ages}

\author{
Dewie Maria Agustin Aplugi ${ }^{1,2}$, Maya Melati ${ }^{3 *}$, Ani Kurniawati ${ }^{3}$, dan Didah Nur Faridah ${ }^{4}$ \\ ${ }^{1}$ Dinas Pertanian Provinsi Nusa Tenggara Timur \\ Jl. Polisi Militer No. 7 Oebufu, Kupang 85111, Indonesia \\ ${ }^{2}$ Program Studi Agronomi dan Hortikultura, Sekolah Pascasarjana, Institut Pertanian Bogor \\ ${ }^{3}$ Departemen Agronomi dan Hortikultura, Fakultas Pertanian, Institut Pertanian Bogor \\ (Bogor Agricultural University), Jl. Meranti, Kampus IPB Dramaga, Bogor 16680, Indonesia \\ ${ }^{4}$ Departemen Ilmu Teknologi Pangan, Fakultas Teknologi Pertanian, Institut Pertanian Bogor (Bogor Agricultural \\ University), Jl. Meranti Kampus IPB Dramaga, Bogor 16680, Indonesia
}

Diterima 27 Maret 2019/Disetujui 14 Juli 2019

\begin{abstract}
Okra (Abelmoschus esculentus L. Moench) is a functional vegetable having high economic value and is used to promote health due to high bioactive compounds and dietary fiber contents. Okra pod is gradually harvested follows flowering time. The purpose of this study was to evaluate the effect of harvest age on Nitrogen (N), Phosphorus (P), Potassium (K), pigment and phenolic contents of two okra varieties. The experiment was conducted from October 2017 to February 2018 at IPB experimental station in Leuwikopo, Dramaga, Bogor (6033'49.3" S and 106043 '30.7" E). The experiment used single factor, namely harvest ages, in randomized complete block nested in factor of okra variety with four replicates. The varieties of okra were Zahira (red okra) and Naila (green okra), while harvest ages consisted of 5, 7, 9, and 11 days after the anthesis (DAA). The results of the study showed significant effect of harvest age on N, P, anthocyanin and phenolic contents. Okra pod harvested at 5 DAA, had the highest $N, P$ and anthocyanin levels; while the highest phenolic level was obtained from okra pod harvested at 7 DAA. There were interactions effect between harvest time and okra varieties on chlorophyll and carotenoid contents. The red okra harvested at 5 DAA had the highest content of total chlorophyll $\left(536.83 \mu \mathrm{g} \mathrm{g}^{-1}\right)$ and carotenoid (147.79 $\left.\mu g g^{-1}\right)$.
\end{abstract}

Keywords: anthocyanin, carotenoid, day after anthesis, green okra, red okra

\section{ABSTRAK}

Okra (Abelmoschus esculentus L. Moench) merupakan sayuran fungsionalyang bernilai ekonomi tinggi dan dimanfaatkan dalam bidang kesehatan, karena mengandung senyawa bioaktif dan serat pangan. Buah okra muda dipanen secara bertahap mengikuti munculnya bunga. Percobaan ini bertujuan mempelajari pengaruh umur panen terhadap kadar Nitrogen (N), Fosfor (P) dan Kalium (K), pigmen dan fenolik pada buah dua varietas okra. Percobaan dilakukan pada bulan Oktober 2017 sampai Februari 2018 di Kebun Percobaan IPB Leuwikopo, Dramaga, Bogor (6033'49.3'LS, 106 43'30.7'BT). Percobaan menggunakan rancangan acak kelompok lengkap tersarang faktor tunggal yaitu umur panen dan diulang sebanyak 4 ulangan. Ulangan tersarang dalam faktor varietas okra terdiri atas Zahira (okra merah) dan Naila (okra hijau) sedangkan faktor umur panen terdiri atas 5, 7, 9, dan 11 hari setelah antesis (HSA). Hasil penelitian menunjukkan bahwa perlakuan umur panen berpengaruh nyata terhadap kadar N, P, antosianin dan fenolik dalam buah okra. Buah yang dipanen 5 HSA mempunyai kadar N, P dan antosianin tertinggi, sedangkan kadar fenolik tertinggi pada buah yang dipanen pada 7 HSA. Terdapat pengaruh interaksi antara perlakuan umur panen dan varietas okra terhadap kadar klorofil total, karotenoid dan kelunakan buah. Okra merah dengan umur panen $5 \mathrm{HSA}$ memiliki kadar klorofil total (536.83 $\left.\mu \mathrm{g} \mathrm{g}^{-1}\right)$ dan kadar karotenoid tertinggi $\left(147.79 \mu g^{-1}\right)$.

Kata kunci: antosianin, hari setelah antesis, karotenoid, okra hijau, okra merah

* Penulis untuk korespondensi. e-mail: mayamelati14@gmail.com 


\section{PENDAHULUAN}

Okra (Abelmoschus esculentus L. Moench) termasuk dalam famili Malvaceae merupakan salah satu sayuran fungsional yang bernilai ekonomi tinggi. Bagian yang dapat dikonsumsi adalah buah, daun, dan biji. Selain sebagai bahan pangan, okra juga bermanfaat dalam bidang industri dan kesehatan (Camciuc et al., 1998). Pemanfaatan okra dalam bidang kesehatan karena mengandung senyawa bioaktif dan serat pangan.

Kandungan bioaktif dalam okra adalah fenolik dan flavonoid (Kumar, 2014). Senyawa fenolik yang dominan dalam buah okra yaitu catechin, epicatechin, procyanidin $\mathrm{B} 1$, procyanidin $\mathrm{B} 2$, rutin dan quercetin (Khomsug et al., 2010). Senyawa-senyawa tersebut bersifat antioksidan (Adetuyi dan Komolafe, 2011), antidiabetes dan antihyperlipidemik (Subrahmanyam et al. 2011), antikanker (Monte et al., 2014), antidepresi (Ebrahimzadeh et al., 2013). Serat pangan yang terkandung dalam buah okra menurut Jain et al. (2012) dan Kumar et al. (2013) yaitu alfaselulosa, hemiselulosa, lignin, pektin, lemak, lilin, dan lendir.

Umur panen penting untuk diperhatikan karena dapat menentukan produksi dan kualitas okra (Piloo dan Kabir, 2011). Hubungan antara umur panen dan kualitas buah okra telah banyak dipelajari. Hasil penelitian Roy et al. (2014) menunjukkan bahwa umur yang tepat untuk memanen buah okra muda yaitu 5-10 hari setelah bunga mekar, dengan panjang polong (buah) antara $6-8 \mathrm{~cm}$ dan dapat dipanen berulang-ulang selama masa produktif sekitar 100 hari setelah tanam (HST). Piloo dan Kabir (2011) menemukan bahwa kadar fenolik total beberapa varietas okra meningkat pada hari ke-5 dan selanjutnya menurun pada hari ke-8 setelah fruit set atau 9 HSA. Selanjutnya menurut Ige dan Eludire (2014), okra dipanen pada umur yang tepat yaitu saat mengandung lendir yang tinggi dan serat kasar lebih sedikit. Balasubramanian et al. (2011) melaporkan bahwa panjang, ketebalan, bobot buah, dan serat kasar bertambah seiring dengan bertambahnya umur panen. Akan tetapi kadar air, vitamin $\mathrm{C}$, protein dan gula menurun dengan bertambahnya umur panen. Umur panen yang tepat diharapkan dapat menghasilkan kualitas okra yang baik.

Perbedaan varietas okra antara lain berdasarkan warna buahnya yaitu merah dan hijau. Penelitian ini menggunakan varietas Zahira yang merupakan okra merah dan Naila yaitu okra dengan warna hijau. Beberapa penelitian telah dilakukan untuk mengetahui kualitas okra, akan tetapi informasi tentang perbandingan kualitas antar varietas akibat perbedaan umur panen masih sangat terbatas. Oleh karena itu, percobaan ini bertujuan untuk mendapatkan informasi tentang kualitas buah okra dari dua varietas yang dipanen pada umur berbeda.

\section{BAHAN DAN METODE}

Percobaan dilaksanakan di Kebun Percobaan IPB Leuwikopo, Kecamatan Dramaga, Kabupaten Bogor, Jawa Barat pada bulan Oktober 2017 hingga bulan Februari 2018. Lokasi percobaan berada pada ketinggian tempat \pm 185 mdpl dengan 6033'49.3" LS dan 106³'30.7” BT. Bahan yang digunakan dalam percobaan ini antara lain benih okra merah (Zahira), benih okra hijau (Naila), pupuk (Urea, ZA, SP 36, $\mathrm{KCl})$.

Percobaan menggunakan rancangan acak kelompok lengkap tersarang faktor tunggal yaitu umur panen dengan ulangan tersarang dalam faktor varietas okra. Faktor umur panen diacak dalam ulangan tersebut. Terdapat dua petak berdasarkan faktor varietas okra. Faktor umur panen terdiri atas 5, 7, 9, dan 11 hari setelah antesis (HSA). Faktor varietas okra yaitu Zahira (okra merah) dan Naila (okra hijau). Ulangan dilakukan sebanyak 4 kali, sehingga terdapat 32 satuan percobaan. Faktor umur panen dianalisis dengan ANOVA, jika berpengaruh nyata dilanjutkan dengan Duncan Multiple Range Test (DMRT) pada taraf 5\%.

Benih okra disemai selama 14 hari, kemudian dipindahkan ke petak percobaan dengan menanam satu bibit per lubang tanam. Penanaman dilakukan pada petak percobaan dengan ukuran $200 \mathrm{~cm}$ x $240 \mathrm{~cm}$ dengan jarak tanam $40 \mathrm{~cm} \mathrm{x} 40 \mathrm{~cm}$, jarak antara petak $100 \mathrm{~cm}$, jarak antara ulangan $200 \mathrm{~cm}$ dan jarak antara varietas okra $19 \mathrm{~m}$. Petak percobaan menggunakan mulsa plastik hitam perak.

Pemupukan dilakukan secara bertahap sebanyak 5 kali yaitu 5 hari sebelum tanam, selanjutnya 15, 40, 65, dan 90 hari setelah pindah tanam (HSP) dengan pupuk yang digunakan adalah $200 \mathrm{~kg}$ Urea ha $^{-1}, 120 \mathrm{~kg} \mathrm{SP} 36 \mathrm{ha}^{-1}, 225$ ZA kg ha-1 dan $150 \mathrm{~kg} \mathrm{KCl} \mathrm{ha}^{-1}$ yang mengacu pada Afandi (2016). Pemanenan dilakukan berdasarkan perlakuan umur panen. Pemanenan dilakukan sampai 100 HSP. Peubah yang diamati yaitu kadar NPK, pigmen dan fenolik total.

Analisis kadar klorofil total, karotenoid dan antosianin menggunakan metode yang diadopsi dari Sims dan Gamon (2002), dilakukan di Laboratorium Pascapanen di Departemen Agronomi dan Hortikultura IPB. Analisis fenolik total dengan menggunakan metode yang diadopsi dari Benites et al. (2015) dilaksanakan di Laboratorium Departemen Ilmu dan Teknologi Pangan.

\section{HASIL DAN PEMBAHASAN}

\section{Kadar dan Kandungan NPK}

Kadar dan kandungan (perkalian antar kadar dan bobot buah) $\mathrm{N}$ dalam buah okra nyata dipengaruhi umur panen namun tidak berbeda nyata antar varietas dan interaksi keduanya. Penundaan umur panen 2, 4, dan 6 hari menurunkan kadar $\mathrm{N}$ buah berturut-turut sebesar $10.8 \%$, $25.5 \%$ dan $36.1 \%$. Sebaliknya, kandungan $\mathrm{N}$ buah okra meningkat seiring dengan penambahan umur panen karena peningkatan ukuran buah. Kandungan $\mathrm{N}$ buah meningkat sebesar $150.92 \%$ dan $319.62 \%$ berturut-turut pada 7 dan 9 HSA (Tabel 1). Hasil percobaan Mirdehghan dan Rahemi (2007) menunjukkan bahwa adanya penurunan kadar nitrogen pada kulit biji dan buah delima seiring dengan pertambahan umur buah dan pada fase kematangan memiliki kadar nitrogen terendah.

Kadar $\mathrm{N}$ dalam buah okra muda pada penelitian ini berada di kisaran 2.2-3.4\% (Tabel 1) artinya berada dalam 
kisaran kecukupan $\mathrm{N}$ jaringan tanaman. Hal ini sejalan dengan penelitian Aziz et al. (2012) yaitu kadar nitrogen dalam buah beberapa varietas okra berada pada kisaran 2.73-2.93\%. Manik et al. (2019) menemukan bahwa kadar $\mathrm{N}$ dalam buah okra dengan pemberian pupuk anorganik sebesar 3.38\%. Menurut McGrath et al. (2014), kisaran kecukupan $\mathrm{N}$ dalam jaringan tanaman adalah 1-5\%, kisaran tersebut berbeda-beda pada masing-masing organ tanaman.

Kadar dan kandungan $\mathrm{P}$ dalam buah okra dipengaruhi oleh umur panen. Kadar P buah okra menurun sebesar $12.28 \%$ dan $17.54 \%$ berturut-turut dengan penundaan umur panen 4 dan 6 hari. Seperti halnya dengan nitrogen, kandungan $\mathrm{P}$ buah okra juga meningkat dengan penundaan umur panen karena pertambahan ukuran buah. Kandungan P buah meningkat sebesar $163.64 \%$ g dan $392.73 \%$ dengan penundaan umur panen 2 dan 4 hari. Kadar P tidak berbeda nyata antara kedua varietas okra, tetapi kandungan $\mathrm{P}$ berbeda nyata antara kedua varietas, kandungan $\mathrm{P}$ tertinggi didapat pada okra hijau (Tabel 1). Penundaan umur panen menyebabkan penurunan kadar $\mathrm{P}$ dalam buah okra, dan hasil ini memiliki kemiripan dengan hasil percobaan yang dilaporkan Mirdehghan dan Rahemi (2007) pada delima tinggi pada awal pertumbuhan buah terutama pada kulit biji dan menurun seiring dengan perkembangan buah terutama pada fase kematangan buah. Penurunan kadar P pada umur panen 7-11 HSA disebabkan oleh mulai terbentuknya biji sehingga kadar $\mathrm{P}$ buah digunakan untuk perkembangan biji. Hal ini mengacu pada penjelasan McGrath et al. (2014) bahwa fosfor penting dalam proses perkembangan tanaman dan komponen jaringan tanaman terutama perkembangan biji.

Kadar P buah okra berada di kisaran 0.47-0.75\%. Kadar $\mathrm{P}$ pada penelitian ini sesuai dengan kadar P pada umumnya dalam buah okra. Kisaran kadar P dalam jaringan tanaman antara 0.1-0.5\% (Marschner, 2012), hal ini menunjukkan kadar P dalam penelitian ini berada dalam kadar kecukupan dalam jaringan tanaman. Aziz et al. (2012) menemukan kadar fosfor dalam buah beberapa varietas okra sebesar 0.49-0.63\%, Gemede (2014) menunjukkan kadar P dalam buah okra sebesar $90 \mathrm{mg} 100 \mathrm{~g}^{-1}$, USDA (2016) menemukan kadar P dalam buah okra sebesar $61 \mathrm{mg} 100 \mathrm{~g}^{-1}$ sedangkan Manik et al. (2019) menemukan bahwa kadar P dalam buah okra adalah $0.56-0.57 \%$.

Secara umum umur panen tidak mempengaruhi kadar K dalam buah okra, kecuali okra merah pada 9 HSA menunjukkan kadar tertinggi yang berbeda nyata dengan kadar K pada 11 HSA (Gambar 1). Kadar K tertinggi, yaitu $4.37 \%$, ditemukan pada buah okra merah yang dipanen pada 9 HSA sedangkan okra hijau yang dipanen pada umur yang sama memiliki kadar K terendah yaitu 3.61\%. Penundaan umur panen 4 hari pada okra merah meningkatkan kadar K sebesar $13.51 \%$, namun menurunkan kadar K okra hijau sebesar $6.71 \%$. Diduga ada perbedaan respon kedua varietas okra terhadap kadar K. Penundaan umur panen 6 hari tidak mempengaruhi kadar K.

Kadar K pada buah okra berada pada kisaran 3.614.37\%. Kadar K yang terkandung dalam buah okra pada penelitian ini cukup tinggi (Gambar 1) dan diduga karena okra mampu menyerap $\mathrm{K}$ untuk proses metabolisme melebihi kebutuhannya. Menurut USDA (2016), dalam $100 \mathrm{~g}$ buah okra terkandung $299 \mathrm{mg} \mathrm{K}$ sedangkan Manik et al. (2019) melaporkan bahwa buah okra memiliki kadar K sebesar 3.58-3.74\%. Marschner (2012), menjelaskan bahwa kisaran kadar kecukupan $\mathrm{K}$ dalam jaringan buah yaitu 1-3\%. Mirdehghan dan Rahemi (2007) menemukan bahwa terjadi penurunan kadar K dalam kulit biji dan buah delima pada saat awal perkembangan buah dan mengalami peningkatan pada saat buah memasuki fase kematangan, terjadi penurunan kadar $\mathrm{K}$ pada setelah fase kematangan buah.

\section{Kandungan Pigmen Buah}

Terdapat perbedaan respon antar varietas terhadap umur panen pada kadar klorofil total (total klorofil a dan b) $(\mathrm{p}<0.01)$. Jika dipanen pada 5 HSA, buah okra merah memiliki kadar klorofil total tertinggi (Gambar 2A). Penundaan panen menyebabkan penurunan kadar

Tabel 1. Pengaruh umur panen dan varietas okra terhadap kadar dan kandungan $\mathrm{N}$ dan $\mathrm{P}$ dalam basis kering

\begin{tabular}{lcccc}
\hline \multirow{2}{*}{ Perlakuan } & $\begin{array}{c}\text { Kadar } \mathrm{N} \\
(\%)\end{array}$ & $\begin{array}{c}\text { Kandungan } \mathrm{N} \\
(\mathrm{g} \text { per buah) }\end{array}$ & $\begin{array}{c}\text { Kadar P } \\
(\%)\end{array}$ & $\begin{array}{c}\text { Kandungan P } \\
(\mathrm{g} \text { per buah) }\end{array}$ \\
\cline { 2 - 5 } & \multicolumn{5}{c}{ basis kering } \\
\hline Umur panen (HSA) & $3.41 \pm 0.04 \mathrm{a}$ & $3.26 \pm 0.12 \mathrm{c}$ & $0.57 \pm 0.01 \mathrm{a}$ & $0.55 \pm 0.23 \mathrm{~d}$ \\
5 & $3.04 \pm 0.08 \mathrm{~b}$ & $8.18 \pm 0.25 \mathrm{~b}$ & $0.54 \pm 0.01 \mathrm{ab}$ & $1.45 \pm 0.02 \mathrm{c}$ \\
7 & $2.54 \pm 0.07 \mathrm{c}$ & $13.68 \pm 0.37 \mathrm{a}$ & $0.50 \pm 0.02 \mathrm{bc}$ & $2.71 \pm 0.12 \mathrm{~b}$ \\
9 & $2.18 \pm 0.06 \mathrm{~d}$ & $14.59 \pm 0.57 \mathrm{a}$ & $0.47 \pm 0.03 \mathrm{c}$ & $3.14 \pm 0.13 \mathrm{a}$ \\
11 & & & & $1.87 \pm 0.25 \mathrm{~b}$ \\
Varietas & $2.84 \pm 0.13$ & $10.02 \pm 1.23$ & $0.51 \pm 0.02$ & $2.05 \pm 0.29 \mathrm{a}$ \\
Zahira (okra merah) & $2.74 \pm 0.13$ & $9.84 \pm 1.18$ & $0.53 \pm 0.01$ & \\
\hline
\end{tabular}

Keterangan: Angka yang dikuti oleh huruf yang berbeda pada kolom yang sama menunjukkan berbeda nyata menurut uji DMRT pada taraf $\alpha=5 \%$, nilai rataan diikuti oleh nilai standar error (se); HSA (hari setelah antesis) 


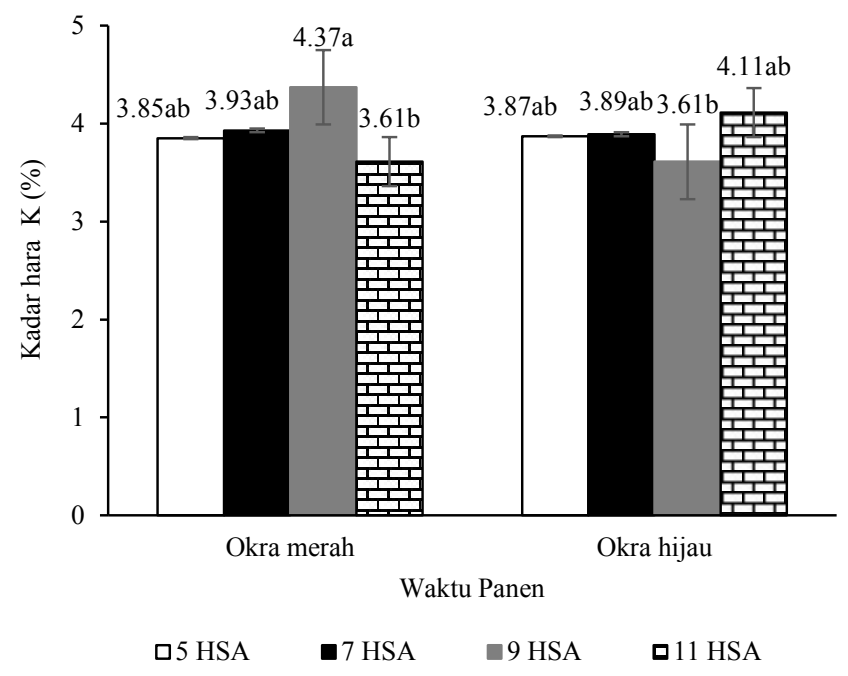

Gambar 1. Kadar K buah masing-masing varietas okra pada berbagai umur panen; HSA (hari setelah antesis)

klorofil total pada kedua varietas okra namun penurunan kadar klorofil total lebih banyak terjadi pada okra merah dibandingkan pada okra hijau. Penundaan panen 2 dan 4 hari menyebabkan menurunnya kadar klorofil total pada okra merah berturut-turut sebesar $38.93 \%$ dan $64.66 \%$, sedangkan pada okra hijau menurun $38.82 \%$ dan $56.49 \%$.

Kadar karotenoid masing-masing varietas okra juga berbeda antar umur panen $(\mathrm{P}<0.05)$. Kadar karotenoid tertinggi pada okra merah dengan umur panen 5 HSA (Gambar 2B). Penundaan umur panen menyebabkan penurunan kadar karotenoid pada kedua varietas okra. Kadar karotenoid menurun $38.47 \%$ dan $65.57 \%$ pada okra merah dengan penundaan umur panen 2 dan 4 hari sedangkan pada okra hijau sebesar 39.51\% dan 57.12\%.

Kadar antosianin dipengaruhi oleh perbedaan umur panen dan bergantung pada varietas okra. Penambahan umur panen 4 hari menurunkan kadar antosianin sebesar $28.41 \%$.
Kadar antosianin berbeda nyata antar kedua varietas okra. Kadar antosianin tertinggi pada okra merah sebesar 0.93 $\mu \mathrm{g} \mathrm{g}^{-1}$, lebih tinggi $43.01 \%$ dibandingkan okra hijau (Tabel $3)$.

Penurunan kadar klorofil total dan karotenoid akibat penundaan umur panen berkaitan dengan peningkatan ukuran dan bobot buah okra. Semakin besar ukuran buah maka semakin berkurang kadar klorofil total dan karotenoid. Terdapat korelasi negatif antara panjang dan bobot buah terhadap kadar klorofil total $(\mathrm{r}=-0.804, \mathrm{r}$ $=-0.772$ ), karotenoid ( $\mathrm{r}=-0.848, \mathrm{r}=-0.822$ ) (Aplugi, 2018). Penambahan umur panen menyebabkan buah okra memasuki fase kematangan buah dan pada fase ini terjadi degradasi pigmen seperti klorofil total, karotenoid dan antosianin. Penelitian Solovchenko et al. (2005) juga menemukan bahwa perubahan warna buah apel terjadi pada fase kematangan disebabkan degradasi klorofil pada buah tersebut. Juansah et al. (2013) menemukan warna buah black mulberry berkorelasi positif dengan kandungan pigmen dan kematangan buah.

Uji korelasi menunjukkan bahwa karotenoid berkorelasi positif dengan klorofil total $(r=0.989)$. Sims dan Gamon (2002) juga mengemukakan bahwa kadar klorofil pada daun berkorelasi positif dengan karotenoid; jika terjadi peningkatan pada kadar klorofil maka dapat diprediksi bahwa kadar karotenoid juga meningkat. Korelasi positif antara kadar klorofil dan karetonoid juga dikemukakan oleh Merzlyak et al. (2003) bahwa kadar klorofil dalam buah apel berkorelasi positif dengan kadar karotenoid.

Hal yang berbeda ditemukan pada pepaya. Sancho et al. (2010) menjelaskan bahwa secara umum terjadinya perubahan warna pada fase kematangan buah pepaya disebabkan oleh berkurangnya klorofil dan munculnya pigmen lain seperti karotenoid yang membuat warna kuning dan warna merah pada buah. Hal ini dimungkinkan karena pepaya merupakan buah klimaterik, fase kematangan pada buah klimaterik terjadi degradasi klorofil oleh enzim
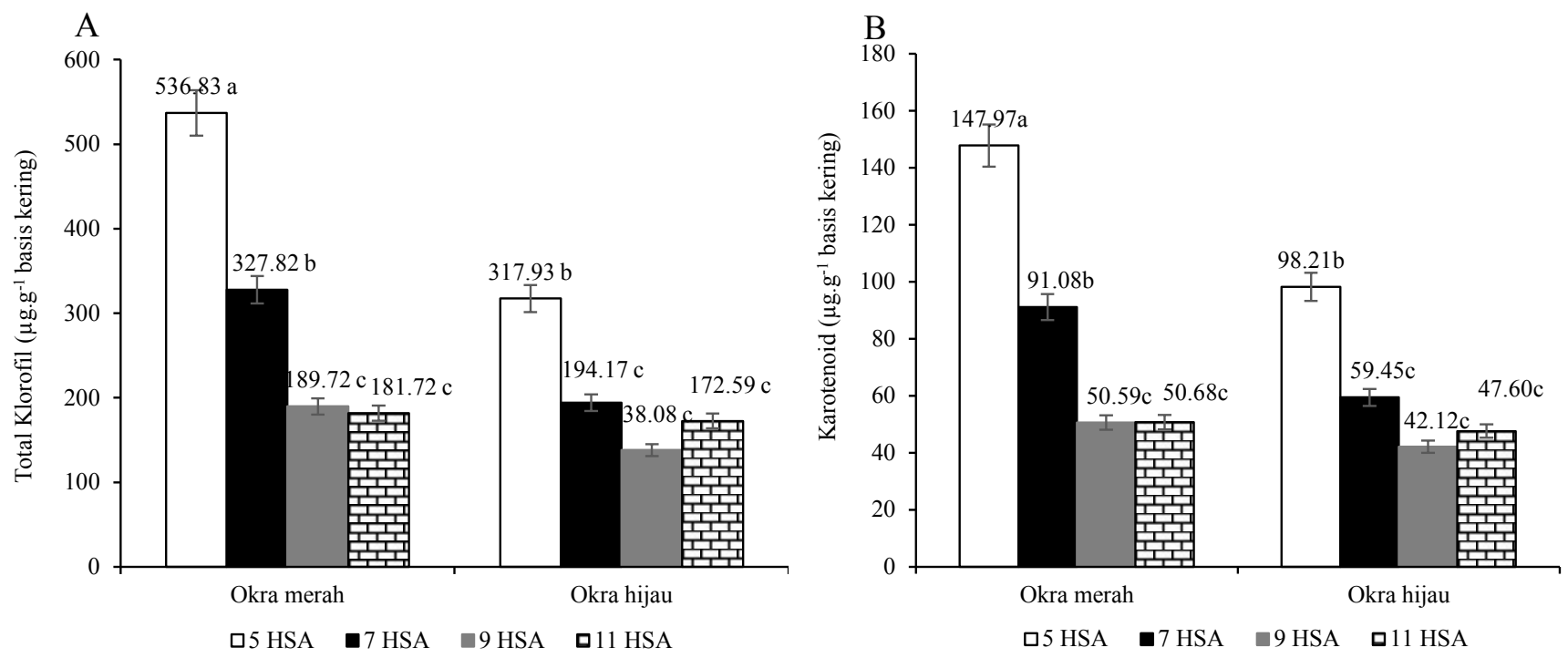

Gambar 2. Kadar klorofil total (A) dan karotenoid (B) buah masing-masing varietas okra pada berbagai umur panen; HSA (hari setelah antesis) 
Tabel 2. Pengaruh umur panen dan varietas okra terhdap kadar antosianin dan fenolik total

\begin{tabular}{lcc}
\hline Perlakuan & $\begin{array}{c}\text { Kadar antosianin } \\
\left(\mu \mathrm{g} \mathrm{g}^{-1} \text { basis }\right. \\
\text { kering })\end{array}$ & $\begin{array}{c}\text { Kadar fenolik } \\
\text { total } \\
\left(\mathrm{mg} \mathrm{g}^{-1} \text { basis }\right. \\
\text { kering })\end{array}$ \\
\hline Umur Panen (HSA) & & \\
5 & $0.88 \pm 0.11 \mathrm{a}$ & $2.41 \pm 0.29 \mathrm{c}$ \\
7 & $0.77 \pm 0.12 \mathrm{ab}$ & $4.27 \pm 0.13 \mathrm{a}$ \\
9 & $0.63 \pm 0.09 \mathrm{~b}$ & $3.48 \pm 0.13 \mathrm{~b}$ \\
11 & $0.64 \pm 0.07 \mathrm{~b}$ & $2.33 \pm 0.17 \mathrm{c}$ \\
Varietas Okra & & \\
Zahira (okra merah) & $0.93 \mathrm{a} \pm 0.06$ & $3.31 \pm 0.24$ \\
Naila (okra hijau) & $0.53 \mathrm{~b} \pm 0.04$ & $2.93 \pm 0.23$ \\
\hline
\end{tabular}

Keterangan: Angka yang dikuti oleh huruf yang sama pada kolom yang sama menunjukkan tidak berbeda nyata menurut uji DMRT pada taraf $\alpha=5 \%$, nilai rataan diikuti oleh nilai standar error (se); HSA (hari setelah antesis)

klorofilase dan meningkatnya karotenoid. Workneh et al. (2012) menyatakan bahwa kadar karotenoid dapat meningkat lima hingga sepuluh kali lipat dari buah berwarna hijau hingga matang penuh.

Kadar pigmen baik klorofil total, karotenoid maupun antosianin pada okra hijau lebih rendah dibandingkan okra merah. Rendahnya kadar pigmen pada okra hijau diduga karena warna hijau buah okra varietas naila adalah hijau terang. Buah dengan warna yang semakin gelap memiliki kadar pigmen lebih tinggi dibandingkan buah dengan warna yang terang. Zhang dan Hamauzu (2003) menemukan kadar karotenoid dan fenolik yang diekstrak dengan metanol pada paprika merah lebih tinggi dibandingkan paprika kuning dan paprika hijau. Kadar karotenoid dan fenolik pada paprika merah sebesar $0.44 \mathrm{mg} 100 \mathrm{~g}^{-1}$ dan $64.5 \mathrm{mg} 100 \mathrm{~g}^{-1}$ sedangkan kadar karotenoid pada paprika hijau sebesar 0.38 mg $100 \mathrm{~g}^{-1}$ dan kadar total fenol sebesar $48.4 \mathrm{mg} 100 \mathrm{~g}^{-1}$.

\section{Kandungan Fenolik Total}

Penambahan umur panen menyebabkan peningkatan kadar fenolik total dalam buah okra (Tabel 2). Umur panen 7 HSA menyebabkan kadar fenolik total tertinggi dan pada 9 dan 11 HSA kadar fenolik total menurun. Penundaan umur panen 2 dan 4 hari meningkatkan kadar fenolik total berturut-turut sebesar $77.18 \%$ dan $44.40 \%$. Penundaan 6 hari tidak mempengaruhi kadar fenolik total dalam buah okra. Kadar fenolik total dalam buah okra tidak berbeda nyata antara kedua varietas okra. Kisaran kadar fenolik total dalam buah okra berkisar antara 2.41-4.27 mg GAE g-1 .

Peningkatan kadar fenolik total pada 7 HSA diduga karena buah okra sudah bisa mensintesis fenolik dan telah memasuki fase pembentukan biji. Terbentuknya biji (meskipun masih muda) mungkin mendorong peningkatan kadar fenolik. Hal ini didukung oleh penemuan Khomsug et al. (2010) bahwa fenolik total dalam biji okra lebih tinggi $24.55 \%$ dibandingkan yang ada dalam buah okra. Peningkatan fenolik total dengan penambahan umur panen juga dilaporkan oleh Sreeshma dan Nair (2013), terjadi peningkatan kadar fenolik total dalam buah okra dengan penundaan umur panen. Pemanenan buah okra pada $1 \mathrm{HSA}$ sebesar $0.024 \mathrm{mg} \mathrm{g}^{-1}$ meningkat menjadi $0.380 \mathrm{mg} \mathrm{g}^{-1}$ pada umur panen 5 HSA dan pada 9 HSA fenolik total sebesar $0.525 \mathrm{mg} \mathrm{g}^{-1}$. Kisaran fenolik total dalam buah okra dengan umur panen 1-9 HSA yaitu 0.024-0.525 mg g-1. Demikian pula yang dilaporkan oleh Piloo dan Kabir (2011) yaitu terjadi peningkatan 5 hari setelah fruit set sebesar $69.96 \%$ dan fenolik total menurun sebesar $19.61 \%$ pada 8 hari setelah fruit set atau 9 HSA. Kisaran fenolik total dalam buah okra pada umur panen 3-9 HSA yaitu $116.05-165.88 \mathrm{mg}^{100 \mathrm{~g}^{-1}}$ Peningkatan tersebut terjadi selama perkembangan buah dan mengalami penurunan pada fase kematangan buah okra.

Berdasarkan kadar fenolik total, buah okra merah varietas Zahira memiliki kualitas yang lebih baik daripada okra hijau. Kadar fenolik tertinggi diperoleh pada buah okra merah dan dipanen pada 7 HSA. Manik et al. (2019) menemukan okra merah (Zahira) mengandung fenolik total

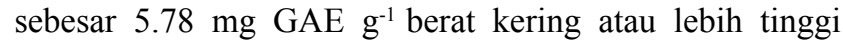
dibandingkan okra hijau (Naila) yaitu sebesar $4.43 \mathrm{mg}$ GAE $\mathrm{g}^{-1}$ berat kering. Okra merah memiliki kandungan pigmen seperti antosianin dan karotenoid yang lebih tinggi dibandingkan okra hijau. Antosianin, karotenoid, dan fenolik merupakan senyawa metabolit sekunder yang bersifat antioksidan dan bermanfaat untuk kesehatan.

\section{KESIMPULAN}

Umur panen secara nyata mempengaruhi kadar $\mathrm{N}$, $\mathrm{P}$, antosianin dan fenolik total. Kadar N, P dan antosianin tertinggi dalam buah yang dipanen pada 5 HSA sedangkan kadar fenolik total tertinggi diperoleh pada umur panen 7 HSA. Terdapat pengaruh interaksi antara varietas okra dan umur panen terhadap kadar K, kadar klorofil total, dan kadar karotenoid. Kadar klorofil total dan karotenoid tertinggi pada okra merah dengan umur panen 5 HSA.

\section{DAFTAR PUSTAKA}

Adetuyi, F.O., A.E. Komolafe. 2011. Effect of the addition of okra seed (Abelmoschus esculentus) flour on the antioxidant properties of plantain Musa paradisiaca flour. Ann. Rev. Res. Biol. 1:143-152.

Afandi, A.L. 2016. Pengaruh pemberian dosis pupuk urea pada beberapa galur terhadap pertumbuhan, hasil dan kualitas okra (Abelmoschus esculentus). Skripsi. Universitas Jember. Jember

Aplugi, D.M.A., 2018. Produksi dan kualitas dua varietas okra (Abelmoshus esculentus L. Moench) dengan perbedaan waktu panen. Tesis. Sekolah Pascasarjana. Institut Pertanian Bogor. Bogor. 
Aziz, A.M., M.U. Hasa, A.Ah, A. Suhail, S.T Sahi. 2012. Role of different physico-chemical characters of okra as a host plant for preference of Earias spp. Pakistan J. Zool. 44:361-369.

Balasubramanian, P., V. Sivakumar, G. Balakrishnamoorthy, R. Balakumbahan. 2011. Standardization of the optimum stage of harvest of bhendi fruits for dehydration/processing. Agric. Res. Comm. Centre Agric. Sci. Digest. 31:121-125.

Benites, R.S.R., A.S.N. Formagio, E.F.S. Argandona, C.R.F. Volobuff, L.N.F. Trevizan, M.C. Viera, M.S. Silvia. 2015. Contents of constituents and antioxidant activity of seed and pulp extracts of Annona coriacea and Annona sylvatica. Brazilian J. Biol. 75:685-691.

Camciuc, M., M. Deplagne, G. Vilanem, A. Gaset.1998. Okra - Abelmoschus esculentus L. (Moench) a crop with economic potential for set aside acreage in France. Indust. Crops Products 7:257-266.

Ebrahimzadeh, M.A., S.M. Nabavi, S.F. Nabafi. 2013. Antidepressant activity of Hibiscus esculentus L. Europ. Rev. Med. Pharmacol. Sci. 17:2609-2612.

Gemede, H.F., N. Ratta, G.D Haki, F. Beyene, A.Z. Woldegiorgis. 2015. Nutritional quality and health benefits of okra (Abelmoschus esculentus): A review. American J. Food Sci. Nutr. 2:1-8.

Ige, O.E., M.O. Eludire. 2014. Floral biology and pollination ecology of okra (Abelmoschus esculentus L. Moench). Amer. Int. J. Biol. 2:1-9.

Jain, N., R. Jain, V. Jain, S. Jain. 2012. Abelmoschus esculentus: Review. Pharmacia 1:84-89.

Juansah, J., R.K. Ariyanti, Akhiruddin. 2013. Potensi metode optik pendugaan kandungan antosianin pada buah black mulberry dan stroberi. J. Biofisika 9:22-30.

Khomsug, P, W. Thongjaroenbuangam, N. Pakdeenarong, M. Suttajit, P. Chantiratikul. 2010. Antioxidative activities and phenolic content of extracts from Okra (Abelmoschuc esculentus L.). Res. J. Biol. Sci. 5:310313.

Kumar, D.S. 2014. Physicochemical, phytochemical and toxicity studies on gum and mucilage from plant Abelmoschus esculentus. J. Phytopharmacol. 3:200203.

Kumar, D.S., D.E. Tony, A.P. Kumar, K.A. Kumar, D.B.S. Rao, R. Nadendla. 2013. A Review on : Abelmoschus esculentus (Okra). Int. Res. J. Pharm. Appl. Sci. 3:129-132.
Manik, A.E.S., M. Melati, A. Kurniawati, D.N. Faridah. 2019. Hasil dan kualitas okra (Abelmoschus esculentus L. Moench) merah dan okra hijau dengan jenis pupuk yang berbeda. J. Agron. Indonesia 47:68-75.

Marschner, P. 2012. Marschner's Mineral Nutrition of Higher Plants. 3rd ed. Waltham: Elsevier Ltd, USA.

McGrath, J.M., J. Sparho, C.J. Penn. 2014. Soil Fertility and Plant Nutrition. Encylopedia of Agriculture and Food Systems. San Diego: Elsevier, USA.

Merzlyak, M.N., A.E. Solovchenko, A.A. Gitelson. 2003. Reflectance spectral features and non-destructive estimation of chlorophyll, carotenoid and anthocyanin content in apple fruit. Postharvest Biol. Tech. 27:197211.

Mirdehghan, S.H., M. Rahemi. 2007. Seasonal changes of mineral nutrients and phenolics in pomegranate (Punica granatum L.) fruit. Sci. Hort. 111:120-127.

Monte, L.G., T. Santi-Gadelha, L.B. Reis, E. Braganbol, R.F. Prietsch, O.A. Dellagostin, R.R.E. Lacerda, C.A.A. Gadelha, F.R.C. Onceicao, L.S. Pinto. 2014. Lectin of Abelmoschus eculentus (okra) promotes selective antitumor effects in human breast cancer cells. Biotechnol. Lett. 36:46-469.

Piloo, N., J. Kabir. 2011. Effect of age of harvest on fruit quality of okra (Abelmoschus esculentus L.). J. Environ. Res. Develop. 5:615-622.

Roy, A., S.L. Shrivastava, S.M. Mandal. 2014. Functional properties of okra Abelmoschus esculentus L. (Moench): traditional claims and scientific evidences. Plant Sci. Today 1:121-130.

Sancho, L.E.G.G., E.M. Yahia, M.A. Martinez-Tellez, G.A. Gonzalez-Aguilar. 2010. Effect of maturity stage of papaya maradol on physiological and biochemical parameters. Am. J. Agri. Biol. Sci. 5:194-203.

Sims, D.A., J.A. Gamon. 2002. Relationships between leaf pigmen content and spectral reflectance across a wide range of species, leaf structure and developmental stages. Remote Sens. Environ. 81:337-354.

Solovchenko, A.E., O.B. Chivkunova, M.N. Merzlyak, V.A. Gudkovsky. 2005. Relationships between chlorophyll and carotenoid pigments during on and off tree ripening of apple fruit as revealed non destructively with reflectance spectroscopy. Postharvest Biol. Technol. 38:9-17.

Sreeshma, L.S., B.R. Nair. 2013. Biochemical changes associated with fruit development in Abelmoschus esculentus cv. Arka Anamika. J. Agric. Technol. 9:373-382. 
Subrahmanyam, G.V., M. Sushma, A. Alekya, C. Neeraja, H. Sai Sri Harsha, J. Ravindra. 2011. Antidiabetic activity of Abelmoschus esculentus fruit extract. Int. J. Res. Pharm. Chem. 1:17-20.

USDA. 2016. Nutrition fact of raw Okra. http://plants.usda. gov/core/profile?symbol=ABES. [09 Maret 2018].
Workneh, T.S., M. Azene, S.Z. Tesfay. 2012. A review on the integrated agrotechonoly of papaya. African J. Biotech. 11:15098-15110. Doi: 10.5897/AJB12.645.

Zhang, D., Y. Hamauzu. 2003. Phenolic compounds, ascorbic acid, carotenoids and antioxidant properties of green, red and yellow bell peppers. J. Food Agric. Environ. 1:22-27. 